\title{
Chromosome Microdissection, Cloning and Painting of the Chromosome 1 in Poplar (Populus tremula)
}

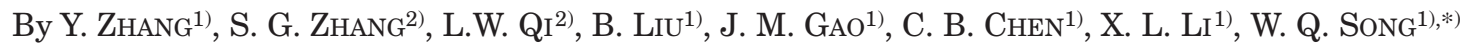

(Received 13 $3^{\text {th }}$ May 2005)

\begin{abstract}
The chromosome microdissection, cloning and painting technology has evolved into an efficient tool for genomic research. Application of these techniques has rarely been applied for forest plants, largely due to the difficulty of chromosome preparation. The present study was performed to establish a method for single chromosome microdissection, cloning and painting in forest plants using poplar (Populus tremula) as a model. An individual chromosome 1 was microdissected from the metaphase spreads of poplar root-tip cells with fine glass needle controlled by a micromanipulator. The dissected chromosome was amplified in vitro by the Sau3A linker adaptor mediated PCR (LA-PCR) technique, by which 200bp to 3,000bp smear DNA fragments were obtained. Then, the second round PCR products from the single chromosome 1 were cloned into T-easy vectors to generate a DNA library of the chromosome 1 . Approximately $3 \times 10^{5}$ recombinant clones were obtained. The second round PCR products were used as a complex probe mixture for fluorescent in situ hybridization (FISH) on the metaphase spreads of poplar. Hybridization signals were observed, mainly, along the entire chromosome 1, at the same time, signals were also present on telomeric and centromeric regions of other chromosomes. Therefore, this research suggests that chromosome microdissection, cloning and painting of the single small chromosome in forest plants are feasible.
\end{abstract}

Key words: Chromosome painting, Fluorescent in situ hybridization (FISH), Microdissection, Populus tremula.

\section{Introduction}

Forest trees are the dominant life form in many ecosystems. They provide structural and functional habitat for two-thirds of the Earth's terrestrial species and contain greater than $90 \%$ of all terrestrial biomass (BRADSHAW et al., 2000; TAYLOR, 2002). Forests cover about 3.8 billion ha., or $30 \%$ of the global land surface. Managed and unmanaged forests throughout the world provide recreational and environmental benefits such as carbon sequestration, renewable energy supplies, watershed protection, improved air quality, biodiversity and habitat for endangered species (Proposal to

\footnotetext{
1) Laboratory of Cell Biology, College of Life Sciences, Nankai University, Tianjin 300071, P. R. China.

$\left.{ }^{2}\right)$ Laboratory of Cell Biology, The Research Institute of Forestry, The Chinese Academy of Forestry, Beijing 100091, P. R. China. Author: Yong ZHANG, Laboratory of Cell Biology, College of Life Sciences, Nankai University, Tianjin 300071, P. R. China. Tel.: 86-22-23508241, Fax: 86-22-23491710, E-mail:

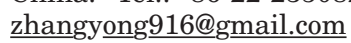

*) Corresponding author: WENQINSONG, Laboratory of Cell Biology, College of Life Sciences, Nankai University, Tianjin 300071 , P. R. China, Tel.: 86-22-23508241, Fax: 86-22-23491710, E-mail: songwq@@nankai.edu.cn
}

sequence Populus Genome white paper, http:// genome.jgi-psf.org/Poptr1/Poptr1.info.html).

The necessity for model species of plants is well recognized and in this role, Arabidopsis thaliana has gained a supreme acceptance amongst plant scientist. While many aspects of tree biology are common to all plants, and hence can be studied in very tractable model species such as Arabidopsis thaliana, some unique facets of tree anatomy and physiology must be investigated in trees themselves. The genus Populus has been adopted as a model for forest tree genetics. Populus, one of only two genera in the family Salicaceae, first occurred in the fossil record ca. 60 MYBP. The genus Populus is especially well suited to serve as the model genome for trees because of the following reasons: 1) a small genome size - the haploid genome size is ca. $480 \pm 20 \mathrm{Mbp}, 2$ ) rapid juvenile growth, 3) ease of clonal propagation and 4) high-throughput transformation and in vitro propagation (BRADSHAW et al., 2000; TAYLOR, 2002; BRUNNER et al., 2004).

A chromosome microdissection and microcloning technology was developed in 1981 (SCALENGHE et al., 1981). Subsequently, it has evolved into an efficient tool for generating chromosome specific DNA libraries of many species (Ponelies et al., 1997; THALHAMMER et al., 2004). This procedure could also be used for the generation of chromosome specific molecular markers, for isolation of chromosome specific sequences using specific PCR primers or for the indirect physical mapping of low/ single copy sequences (HoubEN et al., 2002). With the improvements in the techniques of microdissection and the polymerase chain reaction (PCR), this strategy was simplified largely. Construction of chromosome specific libraries is a potential strategy for the construction of high-density genetic linkage maps of individual chromosomes and the comprehensive analysis of genomes in forest trees. 'Chromosome painting' refers to the hybridization of fluorescently labeled chromosome specific, composite probe pools to cytological preparations. Chromosome painting allows the visualization of individual chromosomes in metaphase or interphase cells and the identification of both numerical and structural chromosomal aberrations with high sensitivity and specificity (RIED et al., 1998). These techniques would also facilitate genomics research in forest trees. However, the application of these techniques to forest trees has seen little reports, largely due to the difficulty of chromosome preparation.

The present study was performed to establish a method for single chromosome microdissection, cloning and painting in forest plants using poplar (Populus tremula) as a model. A single chromosome 1 was 
microdissected from the metaphase spreads of poplar root-tip cells with fine glass needles. The dissected chromosomes were amplified in vitro by the Sau3A linker adaptor-mediated PCR technique. A microclone library of chromosome 1 was constructed. The amplification products were used as a complex probe mixture and hybridized on the metaphase spreads of poplar.

\section{Materials and Methods}

\section{Plant materials}

Populus tremula was used as the experimental material in this study. The branches were collected from the plantation in The Research Institute of Forestry, The Chinese Academy of Forestry.

\section{Preparation of mitotic chromosomes}

Chromosome samples were prepared by wall degradation hypotonic method according to CHEN et al. (1979) with minor modifications. In brief, root tips were removed and immersed successively in saturated paradichlorobenzene for $3 \mathrm{~h}$, in double-distilled water for 30 min, mixed with $2.5 \%(\mathrm{w} / \mathrm{v})$ cellulase and pectinase (Sigma, Germany) for $30 \mathrm{~min}$, rinsed in double-distilled water for $15 \mathrm{~min}$, and finally fixed in $70 \%$ ethanol for 5 min. Put on the fixed material on the sterile coverslip $(22 \times 60-\mathrm{mm})$ and placed drop of $70 \%$ ethanol to them, using a microscope slide as a carrier to stabilize the coverslip. Tore the material and removed the supernatant. Added two drops of $70 \%$ ethanol on the slide, and then dried with hot air. Twenty slides were produced and counted per tree. Metaphase spreads for FISH were prepared on common microscope slide. The quality of chromosome spreading was evaluated under a microscope (80I, Nikon, Japan). Slides with good quality were used for karyotype analysis, chromosome microdissection and FISH.

\section{Karyotype analysis and identification of chromosome 1}

Karyotype analysis was carried out using photographs of clear and well-spreaded metaphase chromosomes according to LI and CHEN (1985). Chromosome 1, the largest chromosome, was identified under a microscope with $1000 x$ magnification (oil objective) based on the result of the karyotype analysis.

\section{Microdissection of chromosome 1}

Each air-dried chromosome specimen was immediately used for microdissection. In the chromosome complements prepared by enzymatic maceration, chromosome 1 was unambiguously identified by its size and shape (the largest chromosome). The target chromosome was isolated using an traditional light microscope (BH-2, Olympus, Janpan) equipped with a micromanipulator (MMO-203, Narishige, Japan) and transferred by a fine glass needle pulled by PC-10 puller (Narishige, Japan) into a $0.5 \mathrm{ml}$ tube according to LI et al. (1998).

\section{Amplification by Sau3A linker adaptor-mediated PCR amplification (LA-PCR)}

The Sau3A linker adaptors, with the sequences 5'CGGGAATTCTGGCTCTGCGACATG-3' and 5'- GATC-
CATGTC-3' were prepared as described by DENG et al. (1992). Isolated chromosomal DNA was treated in $10 \mu \mathrm{l}$ of $50 \mathrm{ng} / \mu \mathrm{l}$ proteinase $\mathrm{K}$ (Merck, Germany) solution at $37^{\circ} \mathrm{C}$ for $2 \mathrm{~h}$. The proteinase $\mathrm{K}$ was then inactivated at $65^{\circ} \mathrm{C}$ for $20 \mathrm{~min}$. The chromosomal DNA was digested by Sau3A $(0.002 \mathrm{U}$ in 1 x T4 ligase buffer, Takara, Japan) at $37^{\circ} \mathrm{C}$ for $2 \mathrm{~h}$. The Sau3A was inactivated at $65^{\circ} \mathrm{C}$ for $20 \mathrm{~min}$, and $20 \mathrm{uM}$ of prepared Sau3A linker adaptors and $1 \mathrm{U}$ of $\mathrm{T} 4$ ligase (Takara, Japan) were added. The ligation between the adaptors and digested chromosomal DNA was performed at $16^{\circ} \mathrm{C}$ for $16 \mathrm{~h}$. The first round of PCR was carried out in the same tube by adding $10 \mu \mathrm{l}$ of $10 \times$ Taq buffer, $6 \mu \mathrm{l}$ of $25 \mathrm{mM} \mathrm{MgCl}_{2}$, $2 \mu \mathrm{l}$ of $10 \mathrm{mM}$ dNTPs, $6 \mu \mathrm{l}$ of $10 \mu \mathrm{M}$ 24-mer primer, $2.5 \mathrm{U}$ of Taq DNA polymerase (Takara, Japan), and distilled water to $100 \mu$ l. PCR amplifications were performed in a thermal cycler (MG 5331, Eppendorf, Germany) using the following programme: after denaturation at $94^{\circ} \mathrm{C}$ for 5 min, amplification was performed with 35 cycles of 1 $\min$ at $94^{\circ} \mathrm{C}, 1 \mathrm{~min}$ at $56^{\circ} \mathrm{C}$, and $2.5 \mathrm{~min}$ at $72^{\circ} \mathrm{C}$, followed by a final extension at $72^{\circ} \mathrm{C}$ for $10 \mathrm{~min}$. The second round of PCR was carried out using $2 \mu \mathrm{l}$ of the firstround products as template. The method was the same as described above, except that 20 cycles of amplification were carried out. To monitor possible extraneous DNA contamination, we maintained a negative control (no template DNA) and a positive control (1 pg genomic DNA as template) throughout the whole process.

\section{Southern blot hybridization analysis}

The poplar genomic DNA was isolated from leaf tissue using CTAB method according to MURRAY and THOMPSON (1980). DNA molecular weight was checked for quality and quantity by agarose gel $(0.8 \%)$ electrophoresis and fluorometry (ND-1000, NanoDrop, America). Appropriate amounts of EcoR I (Takara, Japan) digested genomic DNA, and the two rounds PCR products from chromosome and controls were separated by electrophoresis $(0.8 \%$ agarose $)$ and transferred onto nylon membranes (Pall, America). After the poplar genomic probes had been labeled with digoxygenin (DIG)-11dUTP (Roche, Germany), Southern hybridization and detection were performed following the instructions of the Roche DIG High Prime DNA Labeling and Detection Starter Kit (Roche, Germany).

\section{Construction and characterization of a single chromosome DNA library}

The second LA-PCR products from the isolated poplar chromosome 1 were purified using a DNA purification kit (Sangon, China). A $1 \mu$ l aliquot of the purified DNA (about $100 \mathrm{ng}$ ) was ligated into T-easy vector (Sangon, China) in a $10 \mu \mathrm{l}$ reaction volume at $16^{\circ} \mathrm{C}$ for 16 hours. A $1 \mu \mathrm{l}$ aliquot of the ligation mixture was used to transform Escherichia coli strain DH5a competent cells by heat shock. After co-cultivation in luria broth (LB) medium at $37^{\circ} \mathrm{C}$ for $1 \mathrm{~h}$, one-tenth $(\mathrm{v} / \mathrm{v})$ of the cell solution was plated onto LB plates containing $100 \mathrm{ng} / \mathrm{\mu l}$ of ampicillin, $50 \mathrm{ng} / \mathrm{\mu l}$ of X-Gal and $50 \mathrm{ng} / \mathrm{\mu l}$ IPTG for selection of white colonies. 160 randomly selected recombinant plasmids (white colonies) were isolated by alkaline lysis; the insert DNA was amplified using M13 forward/ 
reverse primer. The sizes of the inserts were estimated by extrapolating to molecular weight standards on a $1.5 \%$ agarose gel. To determine the low/unique or high copy (repetitive sequence) nature of the inserts, DIGlabeled genomic DNA of poplar was hybridized to nylon membranes (Pall, America) containing recombinant clones by dot blotting.

\section{Fluorescence in situ hybridization (FISH)}

The second round PCR products were labelled with DIG-dUTP (Roche, Germany) by randomly-primed DNA synthesis, being used as a complex probe mixture for FISH on the metaphase spreads of poplar. FISH was carried out as described by QI et al. (2002). The slides were examined with a Nikon 80i fluorescence microscope (Nikon, Japan). FISH images of suitable metaphases were acquired and stored with a cooled charge-couple device (Spot Diagnostic, America) equipped with the version 4.0.8 Spot Rtke soft (Spot Diagnostic, America).

\section{Results}

\section{Chromosome preparation and karyotype analysis}

Using root-tip as source material and wall degradation hypotonic method (CHEN et al., 1979), we succeeded in preparing good-quality slides of chromosomes in Pop- ulus tremula. As shown in Fig. 1A, chromosomes were spreaded evenly on the slide with a low background. The somatic chromosome number was $2 \mathrm{n}=2 \mathrm{x}=38$. Twenty slides with good quality were used for karyotype analysis. The result was shown in Fig. $1 B$.

\section{Individual chromosome 1 identification and microdissection}

The precise identification of microdissected chromosomes was an indispensable prerequisite for the reliability of results obtained in this study. According to the established standard karyotype, chromosome 1, the largest submetacentric chromosome, could be identified at prometaphase or metaphase. After being identified and marked, the target chromosome was successfully isolated by a fine glass needle using an improved chromosome microdissection method in our lab (LI et al., 1998) (Fig. 2).

\section{Sau3A linker adaptor-mediated PCR (LA-PCR) amplification of chromosome $1 \mathrm{DNA}$}

In this study, a single chromosome was collected separately into a tube and was used for Sau3A LA-PCR. After two sucessive rounds of amplification, the microdissected chromosomes all yielded products that were observed as bright smear electrophoretic bands of DNA with a range from $200 \mathrm{bp}$ to $2,500 \mathrm{bp}$ on a $1 \%$

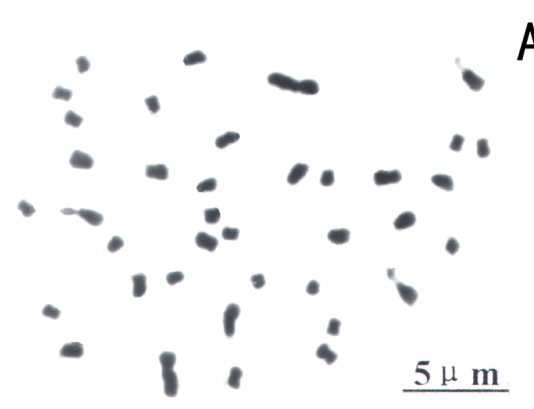

A

B

Figure 1. - Image of Populus tremula somatic metaphase chromosomes (A) and the karyotype (B), scale bar $=5 \mu \mathrm{m}$.
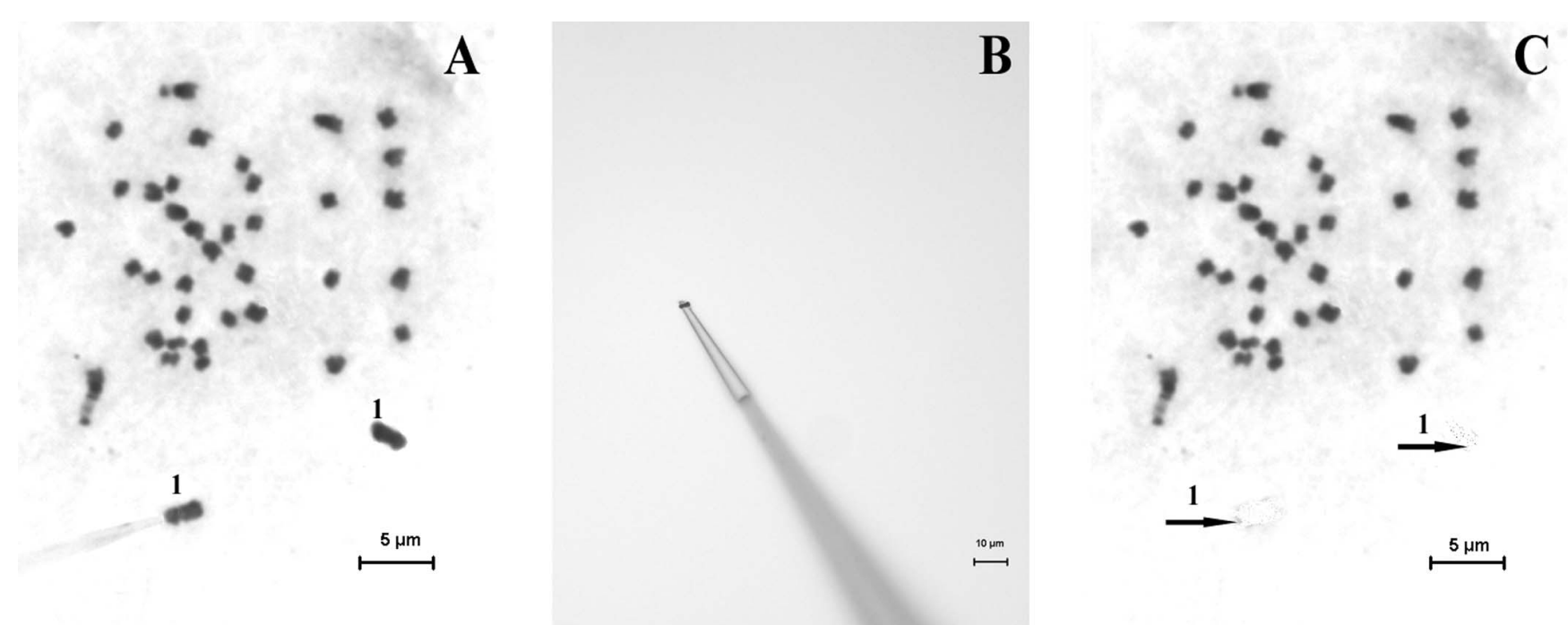

Figure 2. - Procedure of isolation of an individual chromosome 1 in poplar by micromanipulator. A: A Mitotic metaphase image before microdissection of the chromosome 1 (arrow), B: The target chromosome adhering to the tip of a glass needle, C: The individual chromosome 1 in A (arrow) was removed from the cell, scale bar = 5, 10, $5 \mu \mathrm{m}$, respectively. 
agarose gel, with most fragments being concentrated between 300bp and 1,200bp (Fig. 3A, lane 2). At the same time, the positive control with $1 \mathrm{pg}$ of poplar genomic DNA as template for PCR generated products with sizes between 200 bp to 4,000 bp (Fig. 3A, lane 3). As a negative control for monitoring possible contamination with DNA, a sample without template DNA was set up during all stages of the microdissection and amplification procedures. None of the products was amplified from the negative control (Fig. 3A, lane 1). The results indicate that DNA from chromosome 1 was amplified successfully without contamination of exogenous DNA. Southern hybridization with DIG-labeled genomic DNA confirmed that the products were amplified from the poplar genome (Fig. 3B).

\section{Construction of the chromosome 1 specific DNA library}

The second round LA-PCR products from the single chromosomes 1 were used to prepare ligation mixtures for transformation. Approximately $3 \times 10^{5}$ recombinant clones (white colonies) were obtained. 160 randomly selected white colonies were selected for further analysis

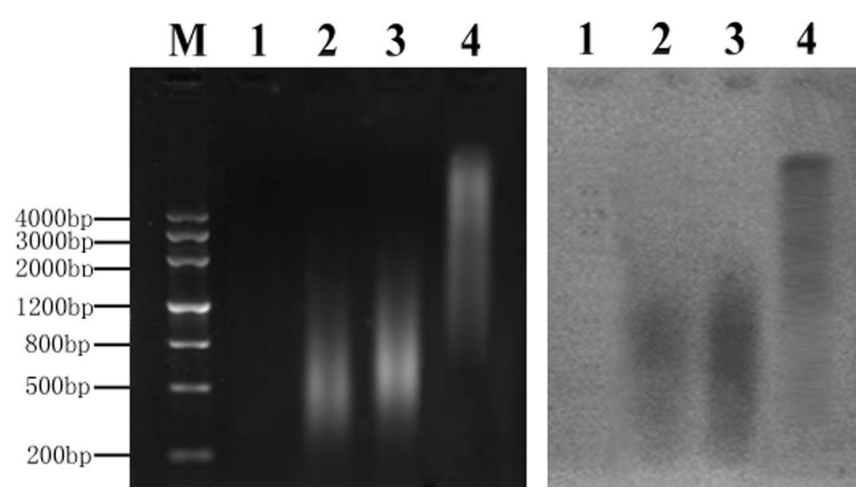

Figure 3. - Linker adaptor-mediated polymerase chain reaction (LA-PCR) amplification with microdissected chromosomes 1 and southern blot hybridization analysis. Left: The LA-PCR products of microdissected chromosomes: the DNA molecularweight mark lane $M$, the negative control (lane 1), the single chromosome 1 as DNA template (lane 2), the positive control (lane 3), EcoRI-digested genomic poplar DNA (lane, 4). Right: Southern blot hybridization of the PCR products with DIGlabeled genomic poplar DNA.
The length of the inserts ranged mainly from 230 to $2,200 \mathrm{bp}$, with an average of $800 \mathrm{bp}$, as estimated by $1.5 \%$ agarose gel electrophoresis (Fig. 4). The colony microarray hybridization analysis were carried out to estimate the copy number of the inserts. Of the 160 clones examined, $40 \%$ represented low/unique copy sequences, while $60 \%$ of the clones were medium or highly repetitive sequences (Fig. 5).

\section{Chromosome painting of chromosome 1}

The LA-PCR products originating from individual microdissected chromosome 1 were labeled with DIGdUTP, and hybridized to mitotic metaphase spreads in the absence of a competitor. Signals were mainly observed uniformly in all chromosomes 1 (Fig. 6A). At the same time, some signals were also observed on the terminal and centromeric regions of other chromosomes (Fig. 6A). Then, unlabeled shared total DNA of poplar was added as a competitor. FISH experiments, which included different probe/competitor combinations, were performed. In all cases, the pattern of signals distributing had not greatly change, although weaker than without pre-hybridization with competitor DNA (even competitor DNA in 100-fold and excess for a $2 \mathrm{~h}$ prehybridization) (data not shown).

\section{Discussion}

\section{Preparation of mitotic chromosomes}

A good-quality chromosome spread was essential in this method and was technically demanding to perform.

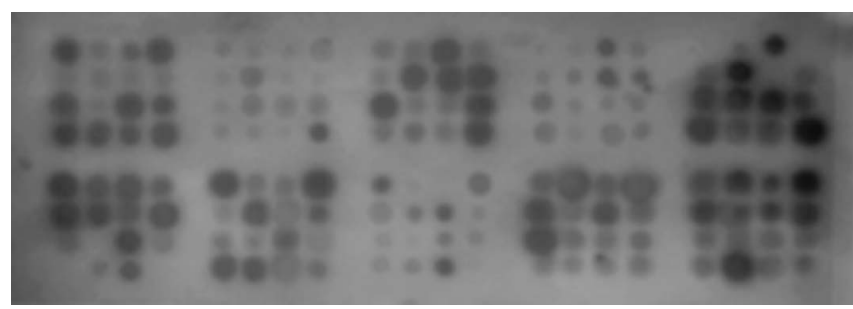

Figure 5. - Result of bacterial colonies hybridization. The 160 randomly selected recombinant clones were positioned on a membrane in a grid microarray. The colony microarray was hybridized with a DIG-labeled genomic poplar DNA probe.

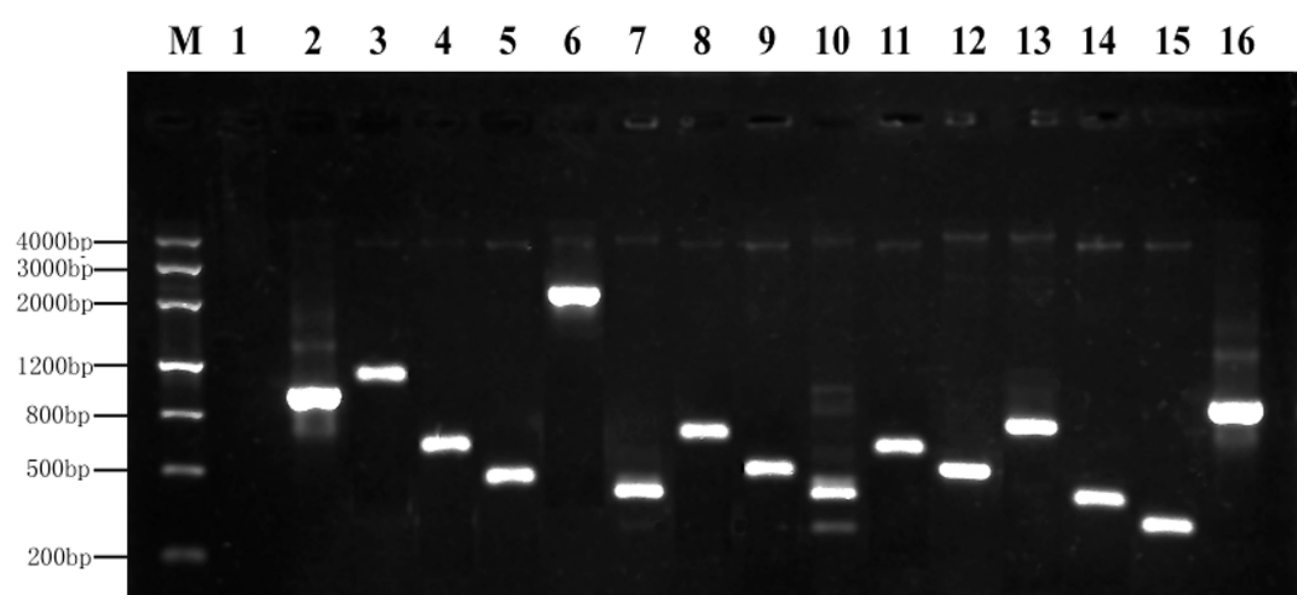

Figure 4. - Partly electrophoresis result of ampified cloning fragments by PCR using M13 forward/reverse primers. 

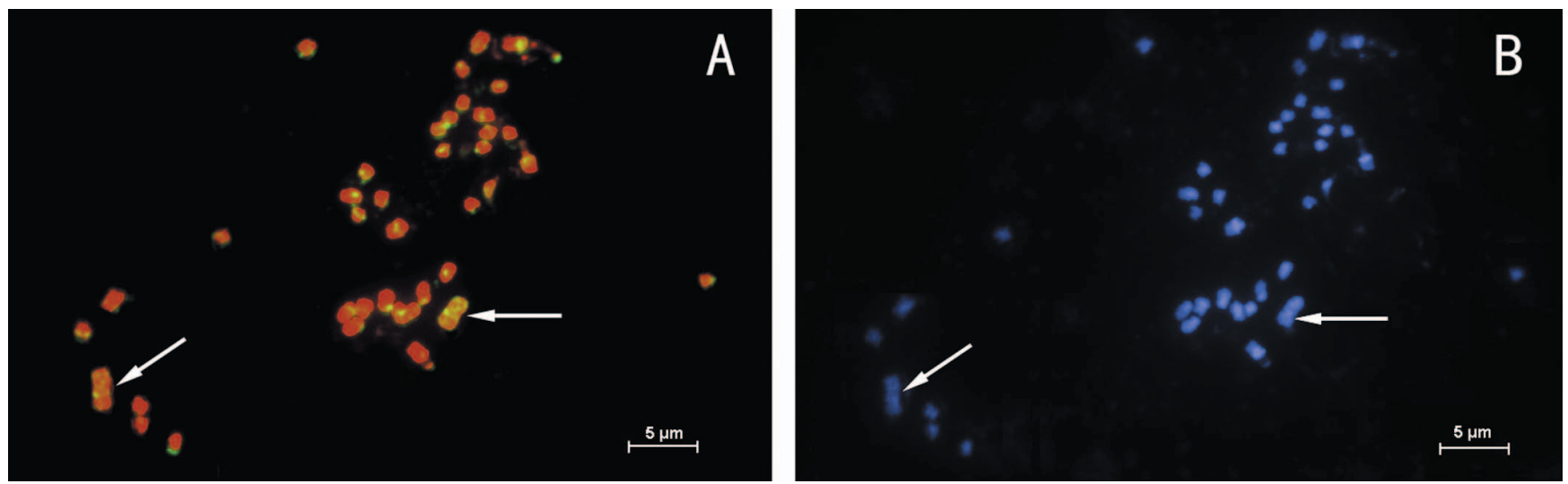

Figure 6. - Result of chromosome painting using microdissection amplification products as prob. A: Metaphase spread of poplar hybridized with labeled LA-PCR products of chromosome 1 without blocking DNA. B: The same chromosomes as shown in A after staining with 4',6-diamidino-2-phenylindole. Arrows indicate the chromosome 1, scale bar $=5 \mu \mathrm{m}$.

This step may be a bottleneck hindering this type of research in poplar because they usually have thick cell walls and were highly lignified, making chromosome spreading difficult. Using root-tip as source material and the wall degradation hypotonic method according to CHEN et al. (1979) with minor modifications, we succeeded in preparing high quality slides of chromosomes of Populus tremula.

The period of chromosome fixation in acetic acid should be as short as possible, because acetic acid damages DNA by depurination. An extended period of fixation in acetic acid could result in relatively short (50-100 bp long) chromosomal DNA fragments (HouBEN et al., 2002). Therefore, we avoided fixing root-tip in fixation solution (methanol : acetic acid $=3: 1$ ) and used $70 \%$ ethanol for short time fixation in chromosome preparation. The chromosome spreads were then prepared in $70 \%$ ethanol instead of $45 \%$ acetic acid. These steps avoided acid depurination and mechanical damage of chromosomal DNA.

\section{Identification and microdissection of target chromosomes}

Correct identification of the target chromosomes is also an important step required for single chromosome microdissection. Generally, this is achieved by choosing plants with target chromosomes bearing prominent morphological features, such as the largest or smallest chromosomes (FUKUI et al., 1992; CHEN and ARMSTRONG, 1995; STEIN et al., 1998; HUANG et al., 2004), or by using specific plant species, for example, monosomic lines (JUNG et al., 1992; VEGA et al., 1994), or tritelosomic lines (Schondelmaier et al., 1993). In Populus tremula, the chromosome 1, the largest submetacentric chromosome, could be unambiguously identified at prometaphase or metaphase. Only metaphases with unequivocally identifiable and spatially well-separated chromosomes were used for microdissection.

However, because of the small sizes of chromosomes in poplar, it is difficult to identify the target chromosome correctly under a $40 \mathrm{x}$ objective. In this paper, we used a technique that was improved by our lab. (LI et al., 1998) for the precise chromosome microdissection by ordinary light microscope. It had not only solved the difficulty of chromosome microdissection by oil objective, but achieved the microdissection on high magnifying multiple (magnification 1,000x 1,500x), and greatly improved the accuracy of chromosome microdissection.

Generally, the sterility requirements to prevent contaminations have to be the same in PCR as for tissue culture. Exceptional care must be taken in preparing reagents for chromosome microdissection to avoid contaminant DNA being amplified (HouBEN et al., 2002). Each working solution is prepared, divided into singleuse aliquots, tested, and used for microdissection only if satisfactory. When preparing solutions, wear gloves and, to the extent it is possible, conduct all manipulations in a laminar flow hood. Irradiate plastic and glassware, buffers and stock solutions (except nucleotides, primers, linker-adaptors and enzymes) with UV light (260 nm wavelength) for 12 hours.

\section{Construction of chromosome specific DNA library}

In this paper, We have successfully constructed a plasmid library from a single microdissected poplar chromosome 1 by used LA-PCR. In previous studies, PCR-mediated cloning was usually performed based on DNA templates provided by several isolated target chromosomes (HoubEN et al., 2002). However, microdissection of specific chromosomes as small as those in poplar is complicated and elaborate work, requiring skill and experience, hence it is impracticable to isolate many copies of the same chromosome from different metaphases. To tackle this problem, we tried to acquire DNA fragments by conducting PCR based on a single copy of a target chromosome template. Conditions for amplification of chromosomal DNA were optimized to detect and amplify DNA between 50-100 femtogram. Our results indicate it is feasible to amplify DNA fragments from a single chromosome with small size for constructing the chromosome specific DNA library.

To date, the cloning efficiency of PCR products from microdissected plant chromosomes has ranged from $2 \mathrm{x}$ $10^{4}$ (JUNG et al., 1992) to $5 \times 10^{5}$ (CHEN and ARMSTRONG, 1995), and then to $4 \times 10^{6}$ (STEIN et al., 1998). All members of the Populus genus have a genome contained 19 nearly identical, metacentric chromosomes, a nuclear 
content of $2 \mathrm{C}=1.2 \mathrm{pg}$ and the haploid genome size of poplar is only ca. $480 \mathrm{Mbp}$ (BRADSHAW et al., 2000; TAYLOR, 2002). Since chromosome 1 covers about $5 \%$ of the genome per haploid (ZHANG et al., 2005), it is deduced to contain $0.06 \mathrm{pg}$ or approximately $24 \mathrm{Mbp}$. The microclone library of chromosome 1 , in this study, included $3 \mathrm{x}$ $10^{5}$ clones, with an average insert size of $800 \mathrm{bp}$. For a $99 \%$ probability that every sequence of chromosome 1 is represented in at least one recombinant clone, $1.4 \times 10^{5}$ clones of chromosome 1 are needed (SAMBRook et al., 1989). So this library maybe can represent the whole of chromosome 1 of poplar, in the main. However, when linker adapter is used for fragment of one restriction enzyme, theoretically there is a possibility of causing bias. Especially the case of highly repetitive sequences the bias became larger. So, till now, none of the chromosome microclone libraries reported could reach a $100 \%$ coverage rate. The way to obtain a genomic library that covers a whole target chromosome would be to employ different combinations of restriction enzymes, adaptors or primers to generate libraries with different complements of DNA sequences (JUNG et al., 1992).

The quality of the chromosome library, on the other hand, is influenced by the enrichment of unique/low copy or chromosome specific sequences. The poplar nuclear genome contains approximately 60\%-80\% repetitive DNA sequences (FLAVELL et al., 1974, 1980; HoubEN et al., 2002). In the library of chromosome 1, the frequency of repetitive inserts was $60 \%$, while that of low/single copy sequences was $40 \%$. Similar results were obtained by CHEN and ARMSTRONG (1995), LiU et al. (1997), StEIN et al. (1998) and ZHOU et al. (1999).

\section{Feasibility of chromosome painting}

The concept of chromosome painting was first introduced in 1988 (Lichter et al., 1988; PINKEL et al., 1988). Chromosome painting has over the last few years become an established procedure in laboratories working with mammalian chromosomes (ANTONACCI et al., 1995). To ensure specific hybridization to related chromosome segments, repetitive sequences need to be excluded from the hybridization process by, for example, pre-hybridization with a large excess of unlabelled total genomic DNA or the fast-reassociating (Cot-1) fraction of genomic DNA (HouBEN et al., 2002).

However, chromosome painting in plants is relatively underdeveloped, although this technique would be useful for evolutionary studies and plant breeding. A comprehensive study by Fuchs et al. (1996) outlines past endeavors to paint chromosomes from various plant species with large genomes (2C DNA content of 11 to 40 pg, such as barley, wheat, Vicia faba, Picea abies). No specific painting of the chromosomes was obtained although a number of different approaches, including pre-hybridization with a large excess of total unlabelled genomic DNA, were tested.

Successful chromosome painting in plants with relatively large genomes has been reported for B chromosomes of Secale cereale (HoUBEN et al., 1996), Brachycome dichromosomatica (HouBEN et al., 1997) and the Y chromosome of Rumex acetosa (SHIBATA et al., 1999).
However, the painting of the described B or Y chromosome was possible because of enrichment for chromosome specific repetitive sequences, rather than the chromosome-specific low- and single-copy sequences which are responsible for painting mammalian chromosomes (HoubEN et al., 2002).

These results were similar to our present study. Hybridization with or without competition by unlabeled genomic DNA showed signals on all the metaphase chromosomes. Our painting pattern indicated that the amplification products of chromosome probably failed to specially label chromosome 1 owing to the presence of a large number of chromosome 1 nonspecific repetitive sequences, which were dispersed at high frequency in the genome. This conclusion accorded with component of chromosome 1 specific DNA library, constructing in this study, in which frequency of repetitive inserts was $60 \%$, while that of low/single copy sequences was $40 \%$. So, we could consider that Chromosome 1 contain large amounts of chromosome specific, repetitive DNA sequences and dispersed repetitive DNA sequences, common to all chromosomes.

Without doubt, with the method described here, the high resolution obtainable by the microdissection of poplar chromosomes could provide a valuable tool for constructing a genetic map, the physical mapping of chromosomes and the isolation of useful genes, as well as improving genetic mapping and comparative genomic researches in poplar.

\section{Acknowledgements}

The authors thank Ms. DULIAN QIU from Sichuan Academy of Agricultural Sciences of China for helpful suggestions on the manuscript. Financial support for this study is from National Key Basic Research Program (“973") (G19990160) - "Molecular Research on Trees Improvement”.

\section{References}

Antonacci, R., R. Marzell, P. Finelli, A. Lonoce, A. Forabosco, N. Archidiacono and M. Rocchi (1995): A panel of subchromosomal painting libraries representing over regions of the human genome. Cytogenet Cell Genet 68: 25-32.

Bradshaw, H. D., R. Ceulemans, J. Davis and R. Stettler (2000): Emerging model systems in plant biology: Poplar (Populus) as a model forest tree. J. Plant Growth Regul. 19: 306-313.

Brunner, A. M., V. B. Busov and S. H. Strauss (2004): Poplar genome sequence: functional genomics in an ecologically dominant plant species. Trends Plant Sci. 9 (1): 49-56.

Chen, Q. and K. Armstrong (1995): Characterization of a library from a single microdissected oat (Avena sativa L.) chromosome. Genome 38: 706-714.

Chen, R. Y., W. Q. Song, X. L. Li and Z. P. AN (1979): A new method of plant mitosis chromosome spread. Acta Botanica Sinica 21: 297-8.

Cheung, W. Y., G. Moore, T. A. Money and M. D. Gale (1992): HpaII library indicates 'methylation-free islands' in wheat and barley. Theor Appl Genet 84: $739-746$. 
Deng, H. X., K. Yoshiura, R. W. Dirks, N. Harada, T. Hirota, K. Tsukamoto, Y. Jinno and N. NiIKAwa (1992): Chromosome-band-specific painting: chromosome in situ suppression hybridization using PCR products from a microdissected chromosome band as a probe pool. Hum Genet. 89 (1): 13-7.

FLAVELL, R. B. (1980): The molecular characterisation and organisation of plant chromosome DNA sequences. Annu Rev Plant Physiol 31: 569-596.

Flavell, R. B., M. D. Bennett, J. B. Smith and D. B. SMITH (1974): Genome size and the proportion of repeated nucleotide sequence DNA in plants. Biochem Genet 12: 257-269.

Fuchs, J., A. Houben, A. Brandes and I. Schubert (1996): Chromosome 'painting' in plants - a feasible technique? Chromosoma 104: 315-320.

Fukui, K., M. Minezawa, K. Kamisugi, M. Ishikawa, N. Ohmido, T. Yanagisawa, M. FuJishita and F. SAKAI (1992): Microdissection of plant chromosomes by argonion laser beam. Theor Appl Genet 84: 787-791.

Houben, A., B. L. Field and V. A. SAunders (2002): Microdissection and chromosome painting of plant B chromosomes. Methods in Cell Science 23: 115-124.

Houben, A., R. G. Kynast, U. Heim, H. Hermann, R. N. Jones and J. W. Forster (1996): Molecular cytogenetic characterisation of the terminal heterochromatic segment of the B-chromosome of rye (Secale cereale). Chromosoma 105: 97-103.

Houben, A., C. R. Leach, D. Verlin, R. Rofe and J. N. Timmis (1997): A repetitive DNA sequence common to the different $\mathrm{B}$ chromosomes of the genus Brachycome. Chromosoma 106: 513-519.

Huang, D., W. Wu, Y. Zhou, Z. Hu and L. Lu (2004): Microdissection and molecular manipulation of single chromosomes in woody fruit trees with small chromosomes using pomelo (Citrus grandis) as a model. I. Construction of single chromosomal DNA libraries. Theor Appl Genet 108: 1366-1370.

Jung, C., U. Claussen, B. Horsthemke, F. Fischer and R. G. HERRMANN (1992): A DNA library from an individual Beta patellaris chromosome conferring nematode resistance obtained by microdissection of meiotic metaphase chromosome. Plant Mol Biol. 20: 503-511.

LI, M. X. and R. Y. CHEN (1985): A suggestion on the standardization of karyotype analysis in plants. Journal of Wuhan Botanical Research 3 (4): 297-302.

LI, X. L., W. Q. Song, W. S. XU and R. Y. Chen (1998): An improved microdissection method of chromosomes. Acta Scientiarum Naturalium Universitatis Nankaiensis 31 (2): 102-105.

Lichter, P., T. Cremer, C. C. Tang, P. C. Watkins, L. MANUELIDIS and D. C. WARD (1988): Rapid detection of human chromosome 21 aberrations by in situ hybridization. Proc Natl Acad Sci USA 85: 9664-9668.

LiU, B., G. Segal, J. M. Vega, M. Feldman and S. AbBo (1997): Isolation and characterization of chromosomespecific DNA sequences from a chromosome arm genomic library of common wheat. Plant J 11: 959-965.

MuRRAY, M. G. and W. F. THOMPSON (1980): Rapid isolation of high molecular weight plant DNA. Nucleic Acids Res. 8 (19): 4321-5.
Pinkel, D., J. Landegent, G. Collins, J. Fuscoe, R. SegRARIS, J. LUCAS and J. GRAY (1988): Fluorescence in situ hybridization with human chromosome-specific libraries: Detection of trisomy 21 and translocations of chromosome 4. Proc Natl Acad Sci USA 85: 9138-9142.

Ponelies, N., N. Stein and G. Weber (1997): Microamplification of specific chromosome sequences; an improved method for genome analysis. Nucleic Acids Research 25 (17): 3555-3557.

QI, Z. X., H. ZenG, X. L. Li, C. B. Chen, W. Q. Song and R. Y. Chen (2002): The molecular characterization of maize B chromosome specific AFLPs. Cell Research 12: 63-8.

RIED, T., E. SCHRÖCK, Y. NING and J. WIENBERG1 (1998): Chromosome painting: a useful art. Human Molecular Genetics 7 (10): 1619-1626.

SAmbrook, J., E. F. Fritsch and T. MANiATis: Molecular cloning: a laboratory manual. Cold Spring Harbor Laboratory press, Cold Spring Harbor, New York.

SAndery, M. J., J. Forster, S. R. Macadam, R. Blunden, R. N. Jones and S. D. M. BRown (1991): Isolation of a sequence common to $\mathrm{A}$ and B-chromosomes of rye (Secale cereale) by microcloning. Plant Mol Biol Rep 9: 21-30.

Scalenghe, F., E. Turco, J. E. Edstrom, V. Pirrotta and M. I. MELLI (1981): Microdissection and cloning of DNA from a specific region of Drosophila melanogaster polytene chromosomes. Chromosoma 82: 205-216.

Schondelmaier, J., R. Martin, A. Jiahoor, A. Houben, A. Graner, H. U. Koop, R. G. Herrmann and C. Jung (1993): Microdissection and microcloning of the barley (Hordeum vulgare L.) chromosome 1HS. Theor Appl Genet 86: 629-636.

ShiBAtA, F., M. Hizume and Y. KuRoki (1999): Chromosome painting of Y chromosomes and isolation of Y-specific repetitive sequence in the diocious plant Rumex acetosa. Chromosoma 108: 266-270.

Stein, N., N. Ponelies, T. Musket, M. McMullen and G. WeBer (1998): Chromosome micro-dissection and region-specific libraries from pachytene chromosomes of maize (Zea mays L.). Plant J 13: 281-289.

TAYLOR, G. (2002): Populus : Arabidopsis for forestry. Do we need a model tree? Ann. Bot. 90: 677-687.

Thalhammer, S., S. Langer, M. R. SPeicher, W. M. Hecki and J. B. GEIGL (2004): Generation of chromosome painting probes from single chromosomes by laser microdissection and linker-adaptor PCR. Chromosome Res 12 (4): 337-43.

Vega, J. M., S. AbBo, M. Feldman and A. A. LeVy (1994): Chromosome painting in plants: in situ hybridization with a DNA probe from a specific microdissected chromosome arm of common wheat. Proc Natl Acad Sci 91: 12041-12045.

Zhang, S. G., L. W. QI, S. Y. HAN, C. B. Chen, X. L. LI, W. Q. Song and R. Y. Chen (2005): Karyotype comparison of Aigeiros in Populus. Acta Horticuluture Sinica. 32 (1): 70-73.

Zhou, Y. H., Z. M. Hu, B. Y. Dang, H. Wang, X. D. Deng, L. L. WANG and Z. H. ChEN (1999): Microdissection and microcloning of rye (Secale cereale L.) chromosome 1R. Chromosoma 108: 250-255.

Zimmer, R., A. Haberfeld and A. M. V. Gebbins (1997): Microisolation of the chicken $\mathrm{Z}$ chromosome and construction of microclone libraries. Genome 40: 865-872. 